\title{
Quality and Potency Analysis of IVY Leaf Extract
}

\author{
Sidra Yasmeen ${ }^{5}$, Rafia Usman', Sultan Ayaz ${ }^{2}$, Fatima Qamar ${ }^{5, *}$, Syeda Zainab ${ }^{5}$, Halima Sadia ${ }^{5}$, Hira \\ Munir $^{3}$, Amaris Arif ${ }^{3}$, Sadia Shakeel ${ }^{4}$, Aqib Zahoor ${ }^{3}$, Kashifa Khanum ${ }^{3}$, Zubair Uddin Faridi ${ }^{5}$ \\ ${ }^{1}$ NED University of Engineering and Technology Karachi, Pakistan \\ ${ }^{2}$ Department of Eastern Medicine, GC University, Faisalabad, Pakistan \\ ${ }^{3}$ Research \& Development, Herbion Pakistan (Pvt) Limited, Karachi. \\ ${ }^{4}$ Faculty of Pharmaceutical Sciences, Dow University of Health Sciences, Karachi \\ ${ }^{5}$ Faculty of Pharmacy, Jinnah University for women, Karachi, Pakistan
}

\begin{abstract}
Authors' Contributions
1 conceived the idea,

1,2,3,4 participated in the design of the study

and wrote the manuscript,

5-10 designed the project.

11,12 editing of the manuscript.

All authors reviewed and approved the final manuscript.
\end{abstract}

\section{Article info.}

Received: November 13, 2019

Accepted: August 23, 2020

Funding Source: Nil

Conflict of Interest: Nil

Cite this article: Usman R, Ayaz S, Munir $\mathrm{H}$, Arif A, Shakeel S, Sadia H, Zahoor A, Khanum

K, Qamar F, Zainab S, Faridi ZU. Quality and

Potency Analysis of IVY Leaf Extract. RADS J

Pharm Pharm Sci. 2020; 8(1):58-62.

*Address of Correspondence Author:

fatimamudassar2009@hotmail.com

\section{A B S TRACT}

Background: Hedera helix generally recognized as Ivy or English Ivy and has been employed since a long time in conventional medication in management of respiratory problems.

Objective of the study: The current study was conducted with the aim to evaluate Ivy leaf extract to authenticate the quality of extract.

Methods: Evaluation was conducted on different physicochemical factors of extract that include physical appearance, organoleptic properties and solubility. Loss on drying, microbial analysis and heavy metal analysis was also carried out to execute the safety of extract. High performance liquid chromatography was executed to evaluate the presence of Hederacoside $\mathrm{C}$ in Ivy leaf extract employing phosphoric acid $85 \%$, acetonitrile, water $(2: 140: 860 \mathrm{v} / \mathrm{v} / \mathrm{v})$ as a mobile phase.

Results: Extract exhibited greenish brown color, distinctive odor and sweet taste. An Ivy extract was found in agreement of the allowable microbial limit as well as with the heavy metal contents limit. The presence of Hederacoside $C$ in Ivy leaf extract was confirmed by HPLC.

Conclusion: The current evaluation reveals conformity with all the analytical procedures. Hence Ivy leaf extract is well standardized formulation at the base line consideration.

Keywords: Analysis; Evaluation; Ivy leaf extract; Hederacoside C

\section{INTRODUCTION}

Hedera helix L. belongs to a family Araliaceae and generally recognized as Ivy or English Ivy. The young leaves extract of the plant has been employed since a long time in conventional medication in management of respiratory problems owed to its broncho spasmolytic and expectorant effects [1]. At present a variety of pharmaceutical formulations of Ivy leaf extract including solid, liquid and semisolid dosage forms are accessible for public to cure the ailments
$[2,3]$. There are several clinical trials conducted using Ivy leaves that have verified the effectiveness and quality of such drugs. Due to the investigational and pragmatic proof on its efficiency and safe use, a noteworthy augmentation of its prescribing practices has been observed in several European countries includes Germany [4]. Mass percentage i.e. greater than $80 \%$ of plant based expectorants recommended in Germany In 2007, consisted of Ivy leaf extract and accounted to almost two million prescriptions countrywide. 
There is a vast variety of chemical constituents that have been isolated from $H$. helix, including polyacetylenes, triterpene, flavonoids, saponins and various phenolic compounds [5]. A triterpene saponin a-hederin, is known to be accountable for the beneficial consequences of Ivy leaf extract since it possess $\beta_{2}$-adrenergic properties [6]. Hederacoside $\mathrm{C}$, an important triterpene saponin, is recognized to be metabolized in the active form and generate the consequences of $\alpha$-hederin in the body $[6,7]$. The current investigation was conducted with the plan to evaluate the quality and potency of Ivy leaf extract.

\section{Experimental}

\section{Extract preparation}

All the herbal drugs to be utilized in the research were sieved by using mesh \#60 and grinded. Every herb was put in extractor; water was used as a solvent in the proportion of $1: 10$ with herbs. Then finally the decoction was obtained and filtered.

\section{Organoleptic evaluation}

Ivy leaf extract was evaluated for its organoleptic properties including color, odour and taste.

\section{Loss on drying}

Before testing, Petri dish was kept in the oven at $105^{\circ} \mathrm{C}$ for 30 minutes and cool the Petri dish by using desiccator and weigh it, the weight was noted as W1. After accurately weighing transfer about $1.0 \mathrm{~g}$ of sample into Petri dish and note down the weight as W2. Petri dish was placed with sample into the oven at $105^{\circ} \mathrm{C}$ for approx $1.5 \mathrm{hr}$. After drying the Petri dish was removed and kept into desiccator. After cooling, the Petri dish was weighed with sample and note down the weigh as W3.

Calculation

$\%$ of loss on drying $=(\mathrm{W} 2-\mathrm{W} 3) \times 100$

$$
(\mathrm{W} 2-\mathrm{Wl})
$$

Where,

$\mathrm{Wl}=$ Weight $(\mathrm{g})$ of the empty weigh bottle

W2 $=$ Weight $(\mathrm{g})$ of the weigh bottle with sample before drying.

W3 = Weight $(\mathrm{g})$ of the weigh bottle with sample after drying.

\section{Assay using High Performance Liquid Chromatography}

\section{Sample preparation}

In 10 volumetric flask, $100 \mathrm{mg}$ of extract was dissolved and diluted using methanol to make up to mark with the same solvent. The solution was then pass through the process of sonification for 30 minutes using ultra sonic bath and filtered by means of a filter having a pore size of $0.45 \mu \mathrm{m}$, proceed for HPLC analysis.

\section{Standard solution preparation}

In a $10 \mathrm{ml}$ volumetric flask, $10 \mathrm{mg}$ of Hederacoside C standard was taken and dissolved using methanol; make up the volume with methanol. The solution was sonicated in the ultra sonic bath. Filter the obtained solution by means of a filter having a pore size of 0.45 $\mu \mathrm{m}$ and use filtrate for chromatography.

\section{Analysis}

$20 \mu \mathrm{L}$ of sample and Hederacoside $\mathrm{C}$ standard solutions were injected and 3 chromatograms in the subsequent conditions were obtained:

Injection sequence was Diluent (blank): 01 followed by Standard: 05 Sample: 02 and Bracket standard: 01 . System suitability was RSD NMT $2.0 \% \quad(5$ replicate injections).Column: Size: $L=250 \mathrm{~mm}, \varnothing=$ $4.6 \mathrm{~mm}$ at $40{ }^{\circ} \mathrm{C}$ column tremperature. Stationary phase: Octadecylsilyl silica gel $(5 \mu \mathrm{m})$. Mobile phase were phosphoric acid $85 \%$, Acetonitrile, water $(2: 140: 860 \mathrm{v} / \mathrm{v} / \mathrm{v})$ (Phase A) and phosphoric acid 85 $\%$, Acetonitrile (2:998 v/v) (Phase A) respectively with $1.5 \mathrm{ml} / \mathrm{min}$ of flow rate at a wavelength of $205 \mathrm{~nm}$.

\section{Gradient system}

\begin{tabular}{|c|c|c|}
\hline $\begin{array}{c}\text { Time } \\
(\mathbf{m i n})\end{array}$ & $\begin{array}{c}\text { Mobile Phase A } \\
(\% \mathbf{v} / \mathbf{v})\end{array}$ & $\begin{array}{c}\text { Mobile Phase } \\
\mathbf{B}(\% \mathbf{v} / \mathbf{v})\end{array}$ \\
\hline 0 & 100 & 0 \\
\hline 40 & 60 & 40 \\
\hline 41 & 0 & 100 \\
\hline 55 & 0 & 100 \\
\hline 56 & 100 & 0 \\
\hline 70 & 100 & 0 \\
\hline
\end{tabular}




\section{Formula:}

$\%$ of Hederacoside $C=\frac{A_{S P L} \times W_{S T D} \times \text { dilution of } s p l \times P}{A_{S T D} \times \text { dilution of } s t d \times W_{S P L} \times 100} \times 100$

Where,

AspL - Average Area of sample

AsTD - average area of standard

$\mathrm{W}_{\mathrm{SPL}}$ - Sample weight, mg

WSTD - Standard weight, mg

P - Percent Purity of standard sample, \%

Note: Quantity of Hederacoside C contents in Ivy leaf extract should NLT 3.0\%

\section{Microbial contamination:}

Microbiological Examination of Ivy leaf extract was carried out as per the of herbal medicinal products for oral use [8].

\section{Determination of heavy metal contents:}

Evaluation of trace elements was carried out by atomic absorption spectrometry flame (FAAS) at the Pakistan Council of Scientific and Industrial Research (PCSIR) Laboratory at Karachi, Pakistan.

\section{RESULTS}

Ivy leaf extract exhibited greenish brown color, typical odor and sweet taste. A vital practice of flavor masking is executed to remove repulsive drugs from getting contact with the taste buds [9]. (Table 1). Determination of physicochemical properties plays a significant part in the quality measurement [10].

Table 1. Organoleptic evaluation of Ivy leaf extract.

\begin{tabular}{|c|c|c|}
\hline Items & Specification & Test Results \\
\hline \multicolumn{2}{|c|}{ Physical \& Chemical Data } \\
\hline Appearance & Fine Powder & Complies \\
\hline Color & $\begin{array}{c}\text { Greenish brown } \\
\text { powder }\end{array}$ & Complies \\
\hline Odour & Characteristic & Complies \\
\hline Solubility & $\begin{array}{c}\text { Soluble in hydro, } \\
\text { Hydro -alcoholic } \\
\text { solutions }\end{array}$ & Complies \\
\hline
\end{tabular}

Table 2. Specifications of Ivy leaf extract.

\begin{tabular}{|c|c|c|}
\hline S.NO & TEST & SPECIFICATIONS \\
\hline 01 & Appearance & $\begin{array}{c}\text { Greenish brown } \\
\text { powder. }\end{array}$ \\
\hline 02 & Identification & $\begin{array}{c}\text { The retention time } \\
\text { for the major peak } \\
\text { in chromatogram } \\
\text { of the Assay } \\
\text { preparation match } \\
\text { to that of the } \\
\text { Standard } \\
\text { preparation. }\end{array}$ \\
\hline 03 & Loss on drying & NMT 5.0\% \\
\hline 04 & Assay & NLT 10.0\% \\
\hline
\end{tabular}

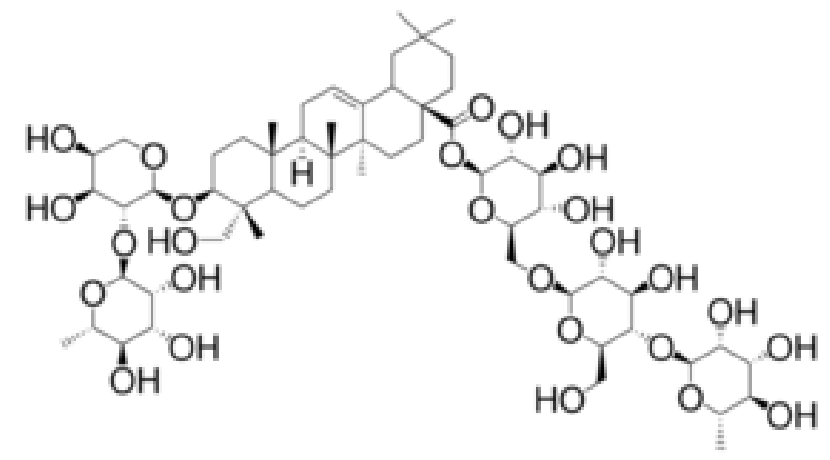

Figure 1. Structure of Hederacoside $C$ found in Ivy leaf extract.

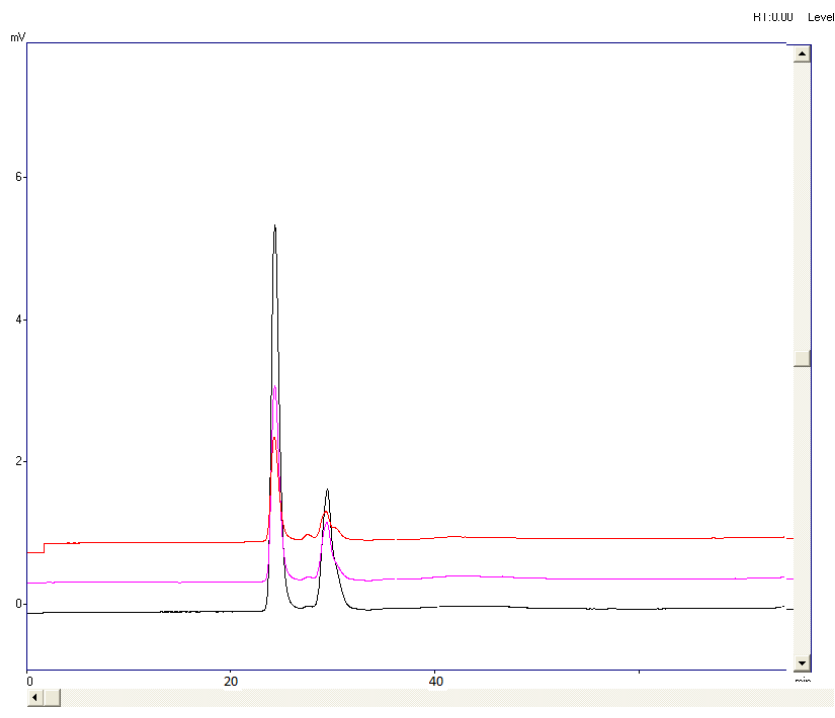

Figure 2. Chromatogram of Hederacoside C. 
Table 3. Acceptable contents for $1 \mathrm{~g}$ of preparation.

\begin{tabular}{|c|c|c|}
\hline $\begin{array}{c}\text { Microbial } \\
\text { Analysis }\end{array}$ & Limit CFU/g & Observation \\
\hline $\begin{array}{c}\text { Aerobic viable } \\
\text { count up }\end{array}$ & NMT $10^{4} \mathrm{CFU} / \mathrm{g}$ & conform \\
\hline Salmonella & not present & not present \\
\hline E. coli & not present & not present \\
\hline S. aureus & not present & not present \\
\hline P. aeruginosa & not present & not present \\
\hline $\begin{array}{c}\text { Entire fungal } \\
\text { count }\end{array}$ & NMT $10^{2} \mathrm{CFU} / \mathrm{g}$ & conform \\
\hline
\end{tabular}

Figure 1 represents the structure of Hederacoside C.Loss on drying and assay results are given in Table 2. Figure 2 represents the structure of Hederacoside C. Massive bacteria may be frequently viewed in soil or derived fertilizers [11,12]. Hence there is enhanced probability for the occurrence of microbial pollution in plant based drugs. An Ivy extract was found concord of the permissible microbial confines. Table 3 Plant based drugs are typically accessible as a blend of more than one plant component and its medicinal action relies on its phytochemical components [13]. Precise recognition and quality assurance is an essential prerequisite to make certain reproducible quality of such drugs [14]. Phytochemical evaluation indicates the quality dimension; include preliminary phytochemical analysis, chemoprofiling, and biomarker examination using novel analytical methods. HPLC is a considerable means for the quantitative phytochemical scrutiny of the plant based drugs. In current study Hederacoside $\mathrm{C}$ an active biomarker of Ivy leaf was detected and the peak of Hederacoside $\mathrm{C}$ complies with standard.

\section{DISCUSSION}

The toxic effects of trace metals on human welfare and the atmosphere have fascinated major contemplation in recent years. The heavy metal contents have small excretion rates that may result in unfavorable consequences on human being still at very low amount. Metals for instance copper, manganese, zinc, iron, and chromium are basic nutrients; required for the basic physiological and natural functions of the human being. On the other hand, an increase in their ingestion over definite acceptable confines can turned out to be noxious. There are numerals of healthiness issues linked to excessive uptake of dietary heavy metals [15]. The elements that have been revealed to be noxious are precisely Arsenic (As), mercury $(\mathrm{Hg})$, Cadmium (Cd) and lead $(\mathrm{Pb})$. The concentration of $\mathrm{As}, \mathrm{Cd}, \mathrm{Pb}$ and $\mathrm{Hg}$ were examined in Ivy leaf extract and they were not detected in extract (Table 4).

Table 4. Heavy metal analysis of extract.

\begin{tabular}{|c|c|c|}
\hline Plant & Specifications & Heavy Metals \\
\hline \multirow{3}{*}{$\begin{array}{c}\text { Hedera } \\
\text { helix L. }\end{array}$} & $\begin{array}{c}\text { Arsenic } \\
\text { (NMT 10 ppm) }\end{array}$ & Not found \\
\cline { 2 - 3 } & $\begin{array}{c}\text { Cadmium } \\
(\text { NMT 0.3 ppm) }\end{array}$ & Not found \\
\cline { 2 - 3 } & Lead (NMT 10 ppm) & Not found \\
\cline { 2 - 3 } & $\begin{array}{c}\text { Mercury } \\
\text { (NMT 1 ppm) }\end{array}$ & Not found \\
\hline
\end{tabular}

\section{CONCLUSIONS}

The current evaluation reveals conformity with all the analytical procedures. The evaluation provides precise and accurate means to develop qualifications for identity, precision and reproducibility of biomarkers in Ivy leaf extract. Hence the extract is well standardized formulation at the base line consideration.

\section{REFERENCES}

1. Yu M, Shin YJ, Kim N, Yoo G, Park S, Kim SH. Determination of saponins and flavonoids in ivy leaf extracts using HPLC-DAD. J. Chromatogr. Sci. 2015;53(4):478-83.

https://doi.org/10.1093/chromsci/bmu068

2. Cwientzek $U$, Ottillinger $B$, Arenberger P. Acute bronchitis therapy with ivy leaves extracts in a twoarm study. A double-blind, randomised study vs. an other ivy leaves extract. Phytomedicine. 201;18(13):1105-9.

https://doi.org/10.1016/j.phymed.2011.06.014

3. Holzinger F, Chenot JF. Systematic review of clinical trials assessing the effectiveness of ivy leaf (hedera helix) for acute upper respiratory tract infections. Evidence-Based Complementary and Alternative Medicine. 2010;2011. https://doi.org/10.1155/2011/382789

4. Büechi $S$, Vögelin $R$, von Eiff $M M$, Ramos $M$, Melzer J. Open trial to assess aspects of safety 
and efficacy of a combined herbal cough syrup with ivy and thyme. Complement Med Res. 2005;12:328-332.

https://doi.org/10.1159/000088934

5. Viougeas MA, Rohr R, Chamel A. Structural changes and permeability of ivy (Hedera helix L.) leaf cuticles in relation to leaf development and after selective chemical treatments. New Phytol. 1995;130(3):337-48.

\section{https://doi.org/10.1111/j.1469- \\ 8137.1995.tb01828.x}

6. Sieben A, Prenner L, Sorkalla T, Wolf A, Jakobs D, Runkel F, Häberlein $H$. a-Hederin, but not hederacoside $\mathrm{C}$ and hederagenin from Hedera helix, affects the binding behavior, dynamics, and regulation of $\beta 2$-adrenergic receptors. Biochem. 2009;48(15):3477-82.

https://doi.org/10.1021/bi802036b

7. Wolf A, Gosens R, Meurs H, Häberlein H. Pretreatment with $\alpha$-hederin increases $\beta$-adrenoceptor mediated relaxation of airway smooth muscle. Phytomedicine. $2011 ; 18(2-3): 214-8$. https://doi.org/10.1016/j.phymed.2010.05.010

8. Bedir E, Kırmızıpekmez H, Sticher O, Çalış İ. Triterpene saponins from the fruits of Hedera helix. Phytochemistry. 2000;53(8):905-9. https://doi.org/10.1016/S0031-9422(99)00503-8

9. Avbunudiogba JA, Alalor CA, Builders PF, Odozie $S$. Development and evaluation of liquid oral phytoformulation of Phyllanthus amarus. J Pharm Res. 2013;6(9):908-12. https://doi.org/10.1016/j.jopr.2013.08.029

10. Modi J, Soni H, Pandya K, Patel G, Patel N. A detail phyto-chemical evaluation of herbo-mineral formulation used in respiratory diseases. $J$ Pharmacogn Phytochemistry. 2014;2(5):36-42.

11. Siddiqui S, Usmanghani $K$, Zahoor A, Sheikh ZA, Khan SS. Quantitative Estimation of Gallic Acid as Biomarker in Lipitame Tablets by HPTLC Densitometry for Diabetic Dyslipidemia. CHIN MED. 2014 Dec 10;5(04):170.

12. Sojitra J, Dave P, Pandya K, Parikh V, Patel P, Patel G. Standardization study of poly herbal formulation-caspa drops. Int J Pharm Sci Drug Res. 2013;5(3):113-9.

13. Kumar V, Malhotra N, Pal T, Chauhan RS. Molecular dissection of pathway components unravel atisine biosynthesis in a non-toxic Aconitum species, A. heterophyllum Wall. 3 Biotech. 2016 1;6(1):106.

14. Rol N, Enow E, Bechem E. Tree seedlings ecology in the undisturbed and disturbed Takamanda Rainforest of south west region, Cameroon. E. Int. J. Adv. Res. Biol. Sci, 2014;1(9), 117-134.

15. Rao A. Trace element estimation-Methods \& clinical context. Online J Health All Sci. 2005;4(1).

This is an Open Access article distributed under the terms of the Creative Commons Attribution License (http://creativecommons.org/licenses/by/4.0), which permits unrestricted use, distribution, and reproduction in any medium, provided the original work is properly cited. 